\title{
Author Correction: Attenuation of RNA polymerase II pausing mitigates BRCA1-associated R-loop accumulation and tumorigenesis
}

Xiaowen Zhang, Huai-Chin Chiang, Yao Wang, Chi Zhang, Sabrina Smith, Xiayan Zhao, Sreejith J. Nair, Joel Michalek, Ismail Jatoi, Meeghan Lautner, Boyce Oliver, Howard Wang, Anna Petit, Teresa Soler, Joan Brunet, Francesca Mateo, Miguel Angel Pujana, Elizabeth Poggi, Krysta Chaldekas, Claudine Isaacs, Beth N. Peshkin, Oscar Ochoa, Frederic Chedin, Constantine Theoharis, Lu-Zhe Sun, Tyler J. Curiel, Richard Elledge, Victor X. Jin, Yanfen Hu \& Rong Li

Nature Communications 8:15908 doi: 10.1038/ncomms15908 (2017); Published 26 Jun 2017; Updated 30 Mar 2018

The original version of this Article omitted the following from the Acknowledgements:

'The work was also supported by a grant to Y.H. from the Cancer Prevention Research Institute of Texas CPRIT RP170126.'

This has been corrected in both the PDF and HTML versions of the Article.

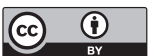

Open Access This article is licensed under a Creative Commons Attribution 4.0 International License, which permits use, sharing, adaptation, distribution and reproduction in any medium or format, as long as you give appropriate credit to the original author(s) and the source, provide a link to the Creative Commons license, and indicate if changes were made. The images or other third party material in this article are included in the article's Creative Commons license, unless indicated otherwise in

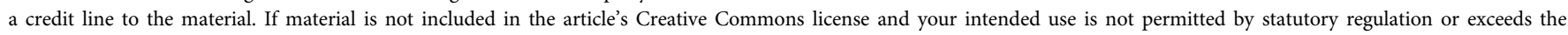
permitted use, you will need to obtain permission directly from the copyright holder. To view a copy of this license, visit http://creativecommons.org/licenses/by/4.0/

(C) The Author(s) 2018 